\title{
AN EXPERIMENTAL STUDY OF IMPACT OF INCLINED HOLLOW PLATE CONTAINING HONEY-BEE WAX AS AN ABSORBER SURFACE IN A SOLAR STILL
}

\author{
V Ramanathan ${ }^{1}$, B Kanimozhi ${ }^{2}$, VK Bhojwani ${ }^{3}$ \\ E-Mail Id: ${ }^{1}$ ramuchetty@gmail.com, ${ }^{2}$ kanihwre@gmail.com, ${ }^{3}$ bhojwanivk@gmail.com \\ 1,2Mechanical Engineering Department, Sathyabama Institute of Science and Technology, Chennai, \\ Tamilnadu, India \\ ${ }^{3}$ Mechanical Engineering Department, MIT-ADT University, Pune, Maharashtra, India
}

\begin{abstract}
In dry-lands across the world, more than two million people are facing difficulty accessing hygienic potable water. The poor people in the remote location of these areas cause a lot of worries to govern bodies to provide drinking water. It is difficult from an economic point to build and operate a water treatment plant, due to less requirement of water as population in these areas is sparse. In such a situation, a solar desalination device can be cost-effective, to produce distilled from brackish groundwater. The thermal efficiency of conventional solar stills is very low along with less productivity.

This experimental work is an attempt to increase the efficiency and productivity of solar still. The increased productivity will make solar distillation economically feasible for poor people. A naturally available phase change material like honey-bee wax has been packed inside a hollow aluminum plate and used as an absorber surface within a solar still. The wax maintains the temperature within $60 \mathrm{oC}$ and stores the excess heat for utilization after sunshine hours. The experimental study was done by comparing it with a conventional still under the same operating conditions. The still with inclined absorber surface shows a $45 \%$ increase in productivity. This is attributed due to extended hours of working of solar still beyond sunshine hours because of latent heat storage and the active model of water flow due to inclined absorber surface.
\end{abstract}

Keywords: Solar Still, PCM, LHS, Parallel Absorber Surface, Desalination, Honey Bee Wax.

\section{INTRODUCTION}

Clean water is essential for the healthy well-being of people. Pollution of water bodies due to human activities around the world is a major cause of worry. In the current scenario, there is a severe water scarcity across the globe due to the increasing population. Desalination is an option to produce potable water in places wherein the freshwater source is scarce. However, the major desalination processes like thermal and reverse-osmosis processes are energyintensive processes. These processes also require a heavy initial investment and running costs due to the requirement of fossil fuels which are not feasible for poor countries and remote places wherein fewer people are living.

A solar desalination device can be a good option in such situations. The initial investment in solar desalination device is very less and zero running cost as solar energy is free and abundant. Focusing on non-conventional energy systems can reduce the pollution that is the need of the hour. The device used for solar desalination is called as a solar still. The process of desalination inside the solar still mimics nature's hydrological cycle by which we receive rain. In the hydrological cycle, the heat from solar energy evaporates seawater into clouds and condensates as rain in low-pressure areas. Similarly, water in the basin of solar still evaporates and condenses beneath the glass surface to give clean potable water.

Solar still are stand-alone systems that can be easily used by everybody with ease. The mere availability of abundant sunshine and some source of saline or brackish water are sufficient to produce potable water. Solar still can be particularly useful in remote locations wherein any conventional energy sources are not available.

An adult person requires a minimum of 3 litres of drinking water for survival. To lead a hygienic life a minimum of 20 litres of water is required per person in a day in developing countries, but some parts this can be met by brackish water also. The typical requirement of clean water is about 5 litres per day per adult. Conventional still with an aperture area of $1 \mathrm{~m} 2$ available in the market can give up to 2.5 litres per day on an average sunny day. Thereby two solar stills are required per person, for a family of 4 persons 8 solar stills will be required. The space constraint arises due to the requirement of $8 \mathrm{~m} 2$ area to install these stills apart from the initial investment required for the systems installed. This paper is an attempt to increase the productivity of solar still without much impact on the cost of the system.

Solar still is not being widely used despite its low cost, simple construction, and easy maintainability. The main cause of limited use is its lower volume of distilled water production per unit area. Hence for wider acceptance and usage, the productivity of solar still must be enhanced without a major change in the cost.

\section{LITERATURE REVIEW}

Due to the benefits of the solar still, many researchers in recent times are working on ways by which the productivity of Still can be increased. The researchers found that productivity can be increased by implementing 
some minor changes in the existing conventional system [1,2]. The heat losses of the system must be reduced [3,4] and by maintaining the temperature difference between the surfaces wherein the evaporation and condensation happen[5]. Some researchers have reported that by increasing the heat capacity by using some latent heat material a better output was achieved [6,7]. But many such changes have increased the cost of the system which renders them economically unfeasible. The focus of the research must be to increase productivity without much change in cost. Amongst the various factors influencing the performance of solar still, water thickness plays a major role along with the system temperature maintained in the range of 50 degrees Celsius is useful in both evaporation and condensation keeping the points in consideration. This research work is done.

\section{RESEARCH METHODOLOGY}

Preliminary work has been done to improve the distillate output. To maintain the thin layer of water a flat plate was kept parallel to and underneath the glass surface [8]. The feed water is supplied in active mode over the flat plate instead of passive mode in the basin of conventional still. Due to the flat plate underneath the glass surface, the temperature of the system rose above 90 degrees Celsius. But the rise in temperature of the system was not beneficial in terms of productivity system. This was due to the fact that at a higher temperature, the condensation was not happening properly. Further feed water was not spread uniformly over the flat plate surface. Therefore to enable the proper spread of feed water over the flat plate, a textile material was introduced above the surface [9]. The modification was beneficial in terms of increased productivity.

Further to increase the productivity the hollow plate was introduced with the phase change material stearic-acid filled in it [10]. The introduction of stearic-acid into the system absorbs the excess heat above 60 degree Celsius of the solar still and emit during the evening time when the sunshine is not available. This modification yielded a better output due to longer working hours of the system. But the stearic acid being an artificial source of phase change material, it chemically disintegrates over a number of cycles. To overcome this problem, a natural source of phase change material that is honey bee wax was tried and tested in this work. A Solar still was developed with a hollow absorber plate filled with honey bee wax. The still that was developed was tested alongside the conventional solar still to test enhancement in productivity.

In this work the absorber surface used is a hollow aluminium plate. It is filled with honey bee wax which will act as latent heat storage by way of phase change from solid to liquid when excess heat is available to the system and utilized during non-sunshine hours by solidification of wax from liquid to solid. Textile material like jute cloth was spread on the surface to ensure the proper spreading of water over this surface and maintain a thin layer to enable proper evaporation from the surface. The feed water is supplied in active mode from an external tank by means of a pipe with a number of drill holes to ensure uniform flow of water. Distilled water from underneath the glass is dripped into the channel beneath the glass from which the water is collected into the collecting bottle. Yet another outlet is provided to collect excess feed water that may not have evaporated from the bottom of the still.

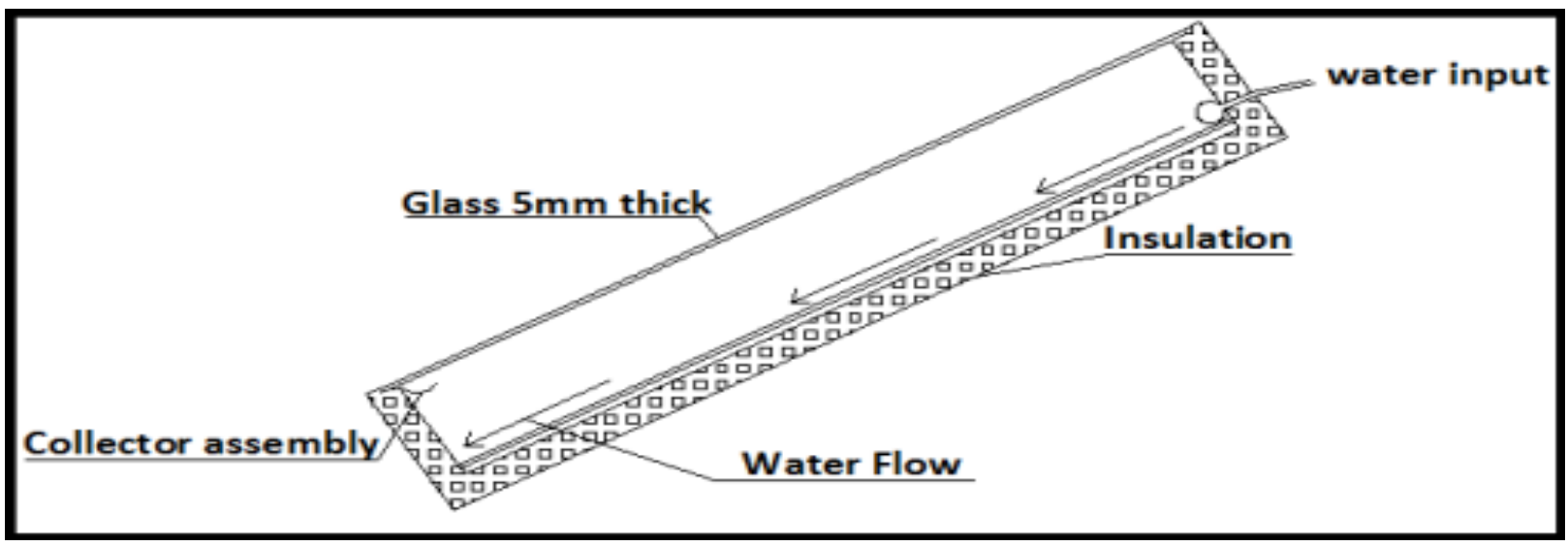

Fig. 3.1 Cross-Sectional View of Modified Solar Still

The fig. 3.1 shows the cross-section of modified still with in which honey-bee wax-filled absorber surface is mounted on a stand at an inclination of 30 degrees with the horizontal surface. The flow rate of the feed water is controlled by a check valve. The water is made to flow over the surface through a pipeline with the number of holes to ensure uniform flow.

The work is done with a sole objective to improve the output of distillate of a conventional still. The still has been developed through a series of experimental work. The performance of the thus obtained system is tested alongside a conventional solar still available in the market. The results of the experiments from both the still were recorded in the month of March 2020 under the same outdoor working conditions. The section following gives the obtained and analysed details.

\section{EXPERIMENTAL WORK AND ANALYSIS}

The basin of conventional still was filled with 10 litres of feed-water whereas in the modified still the water tank reservoir which supplies feed-water in active mode is also filled with 10 litres of water. The check valve is opened in 
such a way to keep the textile material wet enough for evaporation. The honey-bee filled plate also acts as a heat reservoir when the temperature rises above 62 degree Celsius. The distance of travel of evaporated vapour is very less in the case of modified still compared to a large distance in the conventional still. Both the stills were operated in a 24-hour cycle with periodic measurement of temperature and distillate produce from both the stills. The experiment was started at 8:00 am in the morning and readings were taken in an interval of 2 hours. The output of distillate water was measured using calibrated measuring flask.

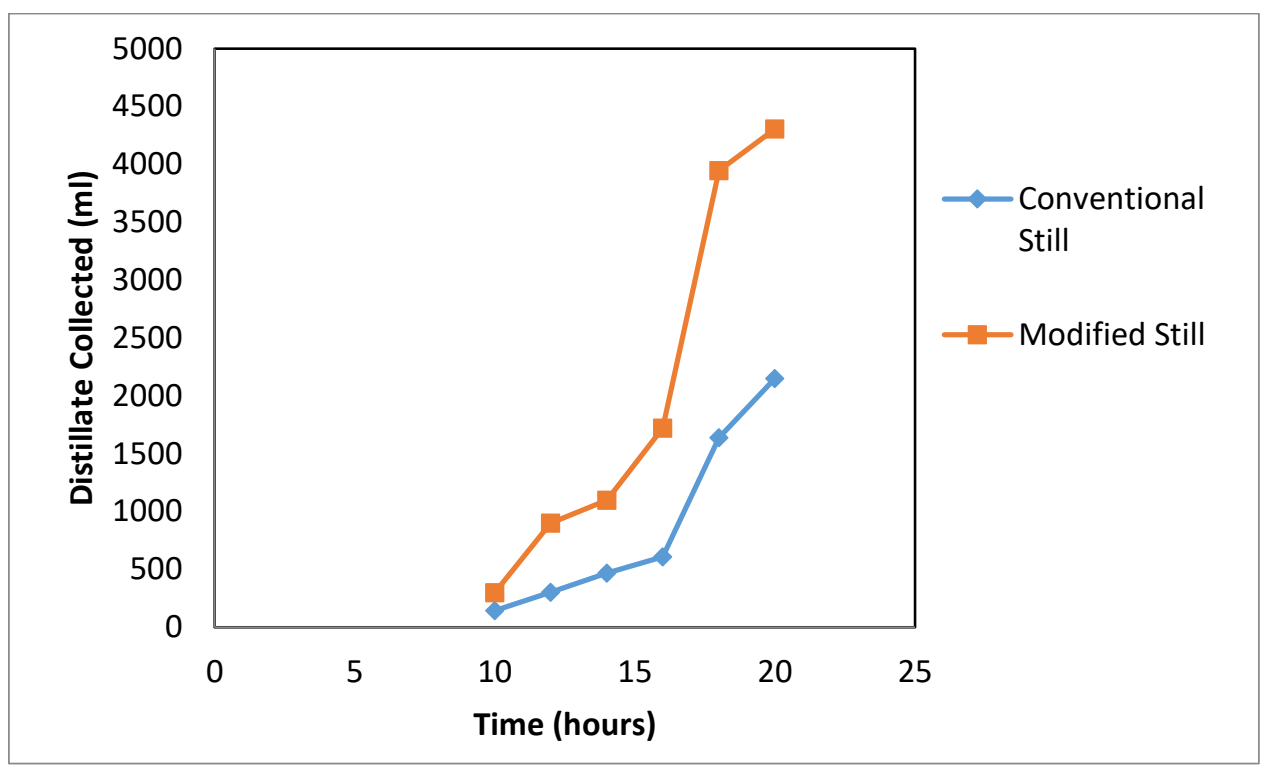

Fig. 4.1 Time Vs Distillate Collected

Fig. 4.1 is the graph is plotted from the result obtained from this 24-hour cycle experiment. The results from the modified still are better than the conventional still. The distilled water output is almost double in modified still when compared to conventional still.

\section{ECONOMIC ANALYSIS}

The conventional still is available in the cost of Rs.8,500 in the market and the modified still is manufactured at a cost of Rs.12,000. Running cost for both the stills are nil except for minor cleaning activities that may be required over a period of time. The effective operation of solar still in a year is around 8 months except for the rainy season. The average output from a conventional system is around 2 litres per day and for modified still, it is around 4 litres per day. At a cost of Rs.15 per litre the revenue generated from the conventional system is Rs.6,000 per year and of modified still is Rs.12,000 per year. The conventional still almost takes 11 months of operation whereas modified still takes less than 6 months of operation to recover the initial investment.

The economic analysis is more cost-effective and smaller payback period. The output of modified still is double the conventional still and the cost incurred is just $40 \%$ more than conventional still. Also, payback period has been reduced by more than 5 months which make modified still a more profitable investment in consideration to a conventional still.

\section{CONCLUSIONS}

The experimental data from the modified still is encouraging when compared to the modified still. The output has doubled. Factors which have led to increased productivity are due to utilization of honeybee wax as latent heat storage medium by phase change, reduced vapour transport distance from the absorber surface to the glass and maintaining of a thin layer of the water layer on the surface of absorber surface. Obtaining double amount of water by the expenditure of Rs.3,000 towards the aluminium plate and honey-bee wax can give double output than the conventional still. Hence the area required for installation also reduces significantly.

\section{REFERENCES}

[1] Bassam et al (2003) Experimental study of a solar still with sponge cubes in the basin, Energy Conversion and Management, 44(9):1411-1418.

[2] Janarthanan, B., Chandrasekaran, J., \& Kumar, S. (2006). Performance of floating cum tilted wick type solar still with the effect of water flowing over the glass cover. Desalination, 190, 51-62.

[3] Kaushal, A., \& Varun. (2010). Solar stills: A review. Renewable and Sustainable Energy Reviews, 14, 446453.

[4] Murugavel, K. K., Chockalingam, K. K. S. K., \& Srithar, K. (2008). Progress in improving the effectiveness of the single basin passive solar still. Desalination, 220, 677-686. 
[5] Sahoo, B. B., Sahoo, N., Mahanta, P., Borbora, L., Kalita, P., \& Saha, U. K. (2008). Performance assessment of a solar still using blackened surface and thermocol insulation.Renewable Energy, 33, 1703-1708.

[6] Valasaraj et al (2002) An experimental study on solar distillation in a single slope basin still by surface heating the water mass, Renewable Energy 25(4):607-612.

[7] Velmurugan, V., Deendayalan, C. K., Vinod, H., \& Srithar, K. (2008). Desalination of affluent using fin-type solar still. Energy, 33, 1719-1727.

[8] Ramanathan, B Kanimozhi, V K Bhojwani (2017), Experimental study on productivity of modified singlebasin solar still with a flat plate absorber, Conf. Series: Materials Science and Engineering 197012032

[9] Ramanathan V, B Kanimozhi, V K Bhojwani, Experimental study on impact of textile material spread over a flat plate absorber on the productivity of modified single-basin solar still, Thermal Science 2020 Volume 24 , Issue 1 Part B, Pages: 591-596.

[10] Ramanathan V, B Kanimozhi \& VK Bhojwani, Experimental Analysis Of An Improvised Solar Still With An Inclined Hollow Absorber Plate Containing Stearic Acid, International Journal of Mechanical and Production Engineering Research and Development, Vol. 10, Special Issue, Jun 2020, 134-140. 